\title{
SCHOOL READINESS SISWA BERKEBUTUHAN KHUSUS DI KELAS INKLUSI TINGKAT SEKOLAH DASAR KOTA BATU
}

\author{
Ni'matuzahroh, Susanti Prasetyaningrum, Ari Firmanto, Putri Saraswati \\ Fakultas Psikologi Universitas Muhammadiyah Malang \\ susanti_p@umm.ac.id, psaraswati@umm.ac.id
}

\begin{abstract}
Abstrak
Kesiapan sekolah merupakan hal yang penting, sebelum siswa menerima materi pelajaran di lingkungan pendidikan. Dengan kesiapan sekolah yang baik anak akan lebih mudah menerima dan memahami pelajaran. Begitupun halnya dengan siswa berkebutuhan khusus, mereka membutuhkan kesiapan dalam memasuki sekolah formal inklusi disebabkan karena banyaknya tuntutan lingkungan yang akan mereka hadapi. Beberapa aspek kesiapan sekolah (school readiness) yang harus dipenuhi siswa inklusi adalah aspek kognitif, sosial, emosi, motivasi dan bahasa. Tujuan penelitian ini untuk mengetahui gambaran kesiapan sekolah siswa berkebutuhan khusus di kelas inklusi. Jenis penelitian yaitu kuantitatif dengan subyek penelitian sebanyak 31 siswa berkebutuhan khusus di kota Batu. Instrument penelitian menggunakan observasi dan wawancara serta dianalisa dengan menggunakan analisa deskriptif. Hasil penelitian menunjukkan rerata kesiapan sekolah (school readiness) pada siswa berkebutuhan khusus aspek bahasa (2,98\%), diikuti aspek emosi (2,80\%), aspek sosial $(2,74 \%)$, aspek kognitif $(2.60 \%)$, dan aspek motivasi $(2.55 \%)$. Hal ini berarti kesiapan sekolah siswa berkebutuhan khusus tingkat sekolah dasar di sekolah inklusi kota Batu yang paling tinggi adalah kesiapan bahasa, diikuti dengan aspek emosi dan sosial. Sedangkan aspek yang paling rendah dalam kesiapan sekolah siswa berkebutuhan khusus di sekolah inklusi Kota Batu adalah aspek motivasi dilanjutkan dengan aspek kognitif.
\end{abstract}

Kata Kunci : School Readiness, siswa berkebutuhan khusus, kelas inklusi

\begin{abstract}
school readiness is importance thing for students before acceptance material education in classroom. Good school readiness make students are easier to accepting and understanding subject. On exceptional students, are need readiness for accepting inclusion formal school, because thera are many social and environment demand feced on them. There are aspects for school readiness are cognitive aspect, social aspect, emotional, motivation anda language. The aim this research to descript psychological profile for school readiness on exceptional students in inclusion classroom. The method of this research is quantitative. The research subject is 31 exceptional students in Batu City. The research instruments are observation and interview. The analysis is description analysis. The result of this research show the contain of school readiness on exceptional students are language aspects $(2,98 \%)$, emotional aspects $(2,80 \%)$, social aspects $(2,74 \%)$, cognitive aspects $(2.60 \%)$, and motivational aspects $(2.55 \%)$. It means, the highest aspects school readiness on exceptional students at inclusion school in Batu city is language aspects. Then, emotional and social aspects. Moreover, the lowest aspects for school readiness on exceptional students in Batu city ismotivational aspects then cognitive aspect.
\end{abstract}

Keyword: School Readiness, exceptional students, inclusion class

(C) 2017 Universitas Muria Kudus 


\section{PENDAHULUAN}

Sekolah dasar merupakan jenjang pendidikan formal yang harus dilalui anak-anak setelah melalui masa bermain di taman kanak-kanak. Di fase ini anak-anak akan mendapatkan tugas dan tanggungjawab yang berbeda dengan saat di sekola taman kanakkanak, sehingga mereka perlu dipersiapkan baik fisik maupun dari sisi psikologis karena di Sekolah Dasar, anak akan belajar lebih formal dan terstruktur dibandingkan di Taman KanakKanak atau di Kelompok Bermain. Di Sekolah Dasar, anak di tuntut lebih berat dalam hal akademik, pribadi dan sosial dibandingkan dengan di TK. Hal ini sesuai dengan tugas perkembangan yang dimiliki anak usia Sekolah Dasar.

Diantara tugas-tugas perkembangan anak menurut Havighurst adalah 1) mengembangkan ketrampilan dasar dalam membaca, menulis dan berhitung; 2) mengembangkan konsep-konsep yang perlu dalam kehidupan sehari-hari; 3) belajar bergaul dengan kelompok sebaya; 4) belajar bekerja dengan kelompok sebaya; 5) mempelajari peran jenis kelamin yang sesuai; 6) belajar menjadi pribadi yang mandiri; 7) mempelajari ketrampilan fisik yang diperlukan; 8) mengembangkan hati nurani dan sistem nilai sebagai pedoman perilaku; 9) mengembangkan sikap terhadap kelompok dan lembaga-lembaga social; 10) mengembangkan konsep diri yang sehat (Munandar, 1985). Oleh karena itu, tingkat pendidikan sebelumnya seperti Taman Kanak-Kanak, dapat membantu untuk membuat anak lebih siap belajar di sekolah. Hal ini dikarenakan saat di TK, anak-anak akan belajar dengan cara yang lebih menyenangkan mengenai aturan, keterampilan sosial, keterampilan pribadi, dan belum dituntut dengan materi akademik yang berat.

Kesiapan sekolah anak dapat dilatihkan dan diajarkan. Kesiapan sekolah merupakan hal yang penting, sebelum seseorang menerima materi pelajaran di lingkungan pendidikan. Dengan kesiapan sekolah yang baik anak akan lebih mudah menerima dan memahami pelajaran. Kesiapan (readiness) dapat diartikan sebagai suatu poin ketika individu telah mencapai level kematangan yang memungkinkan anak untuk belajar perilaku baru, ketrampilan baru dan konsep baru (New \& Cochran, 2007). Dengan demikian, kesiapan sekolah sejatinya berhubungan dengan kematangan baik secara fisik dan psikologi seseorang untuk menerima dan mempelajari hal-hal baru baik ilmu dan perilaku tertentu.

Kondisi fisik dikatakan matang atau siap untuk belajar adalah saat anak sudah mampu mengendalikan dan mengontrol tubuhnya untuk belajar. Koordinasi mata, tangan, kaki penting saat belajar. Kondisi lain yang perlu diperhatikan dalam kesiapan belajar anak adalah kondisi psikologis. Kecerdasan, kemampuan berpikir, kemampuan memahami informasi, kemampuan berinteraksi, kemampuan berkomunikasi, hingga kondisi emosional adalah faktor psikologis yang penting dalam belajar. National Education Goals Panel (1995) memfokuskan gambaran secara keseluruhan mengenai kesiapan sekolah anak, yaitu perkembangan fisik dan motorik, perkembangan sosial dan emosional, pendekatan-pendekatan belajar, 
perkembangan bahasa serta kognitif dan pengetahuan umum. Untuk melihat kesiapan sekolah anak, perlu beberapa pertimbangan seperti ketrampilan bahasa, kesempuraan fisik, ketrampilan mengkoordinasikan motorik, konsentrasi dan emosi serta kemandirian. Disamping itu faktor perkembangan sosial-emosional yang menjadi bagian dari kesiapan anak seperti, kemampuan untuk mengikuti instruksi, kemampuan untuk memberikan fokus perhatian, kemampuan untuk kembali pada tugas, kemampuan mengendalikan diri, kemampuan mengatasi masalah menggunakan kata-kata bukan dengan agresivitas, kemampuan mengerjakan sesuatu dengan mandiri, kemampuan bekerja dalam kelompok, keterampilan sosial dalam berteman, serta keterampilan komunikasi dengan teman dan orang dewasa (Abram, 2012).

Menurut The National E ducation Goals Panel, Kesiapan sekolah juga dapat dilihat dari kesehatan fisik, keterampilan bahasa, perkembangan sosial dan emosional, motivasi belajar, kreativitas dan pengetahuan umum lainnya (council on early childhood, council on school health, 2016). Banyak faktor psikologis yang mempengaruhi kesiapan sekolah anak, termasuk juga dukungan keluarga dan masyarakat.

Pentingnya kesiapan anak dalam belajar dikarenakan akan mempengaruhi kemampuan dan motivasi anak dalam belajar dan berdampak pada performa belajar dan prestasi yang diperoleh anak. Performa akademik yang terlihat karena kurangnya kesiapan sekolah seperti peralatan sekolah yang tidak terbawa atau terlupa, tugas yang tidak lengkap atau tidak selesai hingga perilaku membolos. Sementara itu, kurang siapnya anak dalam belajar juga dapat dilihat dari hasil belajar yang ia peroleh, seperti nilai-nilai yang kurang, prestasi akademik yang minim. Selain itu, dampak lain kesiapan yang kurang dalam menerima pelajaran adalah merasa kurang mampu dan kurang yakinnya anak dalam belajar sehingga berdampak pada kurang percaya diri dan minder di sekolah. Sebaliknya, kesiapan sekolah yang baik akan membawa dampak yang baik. Secara psikologis anak yang siap dalam belajar akan membuat ia nyaman berada di kelas, ia akan bersemangat dalam menerima pelajaran, merasa percaya diri, mampu menyelesaikan tugas sekolah dan meraih prestasi belajar yang baik.

Melihat pentingnya kesiapan sekolah bagi anak yang akan belajar di sekolah, maka kesiapan belajar perlu juga dimiliki oleh anak berkebutuhan khusus, terutama pada anak-anak berkebutuhan khusus yang akan memasuki pendidikan inklusi yaitu pendidikan yang menyertakan semua anak secara bersama-sama dalam suatu iklim dan proses pembelajaran dengan layanan pendidikan yang layak dan sesuai dengan kebutuhan individu peserta didik tanpa membeda-bedakan anak yang berasal dari latar suku, kondisi sosial, kemampuan ekonomi, politik, keluarga, bahasa, geografis (keterpencilan) tempat tinggal, jenis kelamin, agama, dan perbedaan kondisi fisik atau mental, dalam pendidikan inklusi ini semua anak berkebutuhan khusus bersama-sama dengan anak normal lainnya dididik bersama-sama 
untuk mengembangkan potensi mereka (Sapon-Shevin, dalam O Neil, (1997); Smith (2012); Direktorat Pembinaan SLB, 2007) konsep ini dilandasai oleh suatu kenyataan bahwa di dalam masyarakat terdapat anak normal dan anak tidak normal (berkebutuhan khusus) yang tidak dapat dipisahkan sebagai suatu komunitas sosial. sehingga sangat penting kesiapan mereka baik fisik, kognitif, sosial dan emosinya disiapkan agar mereka tidak mengalami stress karena menghadapi situasi dan tuntutan baru. Tujuan utama dari pendidikan inklusif adalah untuk mendidik anak berkebutuhan khusus dikelas reguler bersama-sama dengan anak normal dengan dukungan yang sesuai dengan kebutuhannya disekolah yang terdekat dengan tempat tinggalnya dan tanpa adanya sikap diskriminatif (Stubbs, 2002; Direktorat pembinaan SLB, 2007; Direktorat pembinaan SLB, 2007).

Kesiapan mereka dalam memasuki pendidikan inklusi juga perlu mempertimbangkan karakter khusus yang khas yang mereka miliki dan sangat beragam yang membuat kemampuan intelektual, kecerdasan, kemampuan bersosialisai, kemampuan komunikasi, kemampuan motorik hingga emosinya, karena meskipun secara konsep pendidikan inklusi tampak ideal namun, dalam prakteknya masih banyak kelemahan-kelamahan yang disebabkan kurangnya kesiapan sekolah meliputi kurangnya kompetensi pengajar, terbatasnya kurikulum yang berdiferensiasi sesuai dengan kapasitas siswa $A B K$, kesadaran dan pemahaman teman sebaya dan orang tuanya tentang kehadiran siswa ABK di sekolah, terbatasnya pengawasan dari pemerintah, terbatasanya sumber daya manusia, dan terbatasnya infrastruktur yang berdampak pada kurang optimalnya pelaksananan pendidikan inklusi (Ni'matuzahroh \& Nurhamida, 2014), sehingga berdampak pada perlakuan terhadap siswa berkebutuhan khusus seperti sikap yang buruk dari siswa regular dll membuat kesiapan sekolah siswa berkebutuhan khusus ini menjadi sangat penting. Fenomena tersebut menjadikan peneliti tertarik untuk mengetahui bagaimanakah gambaran kesiapan sekolah siswa berkebutuhan khusus tingkat sekolah dasar ditinjau dari berbagai potensi psikologisnyaambaran

Oleh karena itu, penelitian ini dilakukan untuk mengetahui sejauhmana kesiapan sekolah anak berkebutuhan khusus baik dari aspek kognitif, sosial, emosi, dan motorik siswa ABK dalam mengikuti kelas inklusi. Aspek manakah yang paling dominan dalam menentukan kesiapan siswa berkebutuhan khusus dalam mengikuti kelas inklusi. Penelitian ini diharapkan mampu memberikan gambaran bagi sekolah tentang kondisi kesiapan sekolah siswa inklusi sehingga para guru mampu memberikan pengajaran yang sesuai dengan kebutuhan siswa berkebutuhan khusus, sebagai informasi bagi pemerintah dan pembuat kebijakan untuk memfasilitasi sarana dan prasarana bagi siswa ABK agar mampu berkembang secara optimal. 
Pengertian School Readiness/Kesiapan sekolah

Kesiapan sekolah adalah ditujukan untuk anak agar siap belajar di sekolah. Kesiapan sekolah menjadi perhatian dikalangan profesional pendidikan dan para pembuat kebijakan di banyak negara. Hal ini disebabkan karena banyak penelitian yang menunjukkan bahwa bagaimana anak di sekolah tergantung dari kesiapan anak untuk belajar di sekolah (Heriot \& Beale, 2004). Kesiapan (readiness) dapat diartikan sebagai suatu poin ketika individu telah mencapai level kematangan yang memungkinkan anak untuk belajar perilaku baru, ketrampilan baru dan konsep baru (New \& Cochran, 2007). Dari definisi ini dapat diketahui bahwa kesiapan sekolah adalah masa ketika anak siap untuk belajar perilaku, keterampilan dan konsep baru di sekolah, seperti belajar perilaku berbagi, mengantri; belajar keterampilan menggunting, melipat, bernyanyi, serta belajar konsep baru seperti menolong, bersabar.

Kesiapan sekolah tidak terbatas pada satu area perkembangan atau fungsi melainkan merupakan hubungan timbal balik antara keterampilan dan perilaku melalui aspek perkembangan dan belajar (Denton 2000; Schoen \& Nagle 2004).

\section{Aspek-aspek School Readiness}

Terdapat lima dimensi penting yang mempengaruhi perkembangan anak yang berhubungan dengan kesiapan sekolah (Wooleson, 1995), antara lain:

1. Perkembangan belajar, yakni kemampuan belajar anak mulai dari anak mendapatkan pengetahuan dari pengalaman masa lalunya dan menggunakannya untuk memahami pengalamannya di masa datang. Istilah yang familiar untuk dimensi ini adalah inteligensi.

2. Perkembangan gerak, adalah variasi keterampilan-keterampilan yang membantu anak dalam mengkoordinasikan tangan, kaki dan menjaga keseimbangannya.

3. Perkembangan bicara, yakni pemahaman anak terhadap apa yang dikatakan kepadanya dan kemampuan anak menggunakan kata-kata untuk mengungkapan keinginan dan perasaannya.

4. Perkembangan diri, perkembangan ini berhubungan dengan kepercayaan diri anak. Jika ia merasakan baik pada dirinya maka ia akan nyaman berada di sekolah.

5. Perkembangan dalam mengontrol tangan, terdapat banyak tugas dan aktivitas pada usia ini, meliputi kemampuan anak dalam mengontrol tangannya. Misalnya, bagaimana ia memegang crayon ketika menggambar, bagaimana ia memegang sendok ketika makan.

Sementara menurut Unicef (2012), terdapat tiga dimensi kesiapan sekolah yaitu:

1. Anak yang Siap, menekankan pada belajar dan perkembangan anak. Definisi kesiapan sekolah adalah holistik dan mencakup lima domain yang berhubungan dengan performa dan perilaku di sekolah kelak, yakni kesejahteraan fisik dan perkembangan motor, 
perkembangan bahasa, perkembangan sosial dan emosional, pendekatan belajar, pengetahuan umum dan kognitif mencakup matematika.

a. Aspek sosial-emosional meliputi mempertahankan perhatian, regulasi emosi, mengikuti instruksi, hubungan sosial dan kognisi social

b. Bahasa dan literasi meliputi bahasa yang disampaikan dan kefasihan bahasa.).

c. Sedangkan keterampilan matematika meliputi pemahaman awal konsep matematika, pengukuran, keterampilan pra-berhitung

d. Sikap belajar meliputi ketekunan terhadap tugas, perhatian, kreativitas, inisiatif, rasa ingin tahu dan kemampuan menyelesaikan masalah.

2. Sekolah yang siap, menekankan pada lingkungan sekolah yang mendukung transisi anak-anak masuk ke dalam sekolah dasar dan menengah serta menyediakan fasilitas belajar bagi anak. Kualitas dilihat dari beberapa karakteristik yang berhubungan dengan sekolah yang siap, meliputi waktu yang cukup untuk belajar di kelas, material belajar yang mendukung seperti buku dan alat bantu pengajaran, efektivitas pengajaran, penerapan pendidikan pedagogi dan kompetensi guru. Serta hubungan guru dan anak yang dapat membangun perkembangan sosial, etika, emosi, intelektual dan kompetensi fisik (Shore 1998 dalam unicef, 2012). Lingkungan sekolah anak yang ramah menydiakan kesehatan (gizi, program imunisasi), kebersihan (menyediakan lingkungan dan air bersih, sanitasi), keamanan (konstrusi bangunan yang aman, tempat bermain), perlindungan (dari hukuman, kekerasan) dan kesetaraan gender.

3. Keluarga yang siap, menekankan pada pengasuhan dan sikap pengasuh serta lingkungan tempat anak pertama kali belajar dan berkembang menuju transisi ke sekolah. Keluarga dipahami sebagai anggota yang membantu membesarkan anak meliputi pengasuh biologis, non-iologis, saudara, keluarga besar. kesiapan keluarga meliputi praktek pengasuhan, sikap dan pengetahuan tentang kesiapan sekolah meliputi, tahun awal masuk sekolah, persiapan keluarga untuk anaknya bersekolah mulai dari lahir (Brazelton \& Greenspan, 2000).

4. Orang tua dan praktek budaya yang diterapkan meliputi penggunaan bahasa pertama anak (Villegas \& Lucas 2002).

5. Status sosial ekonomi, meliputi penghasilan, pekerjaan keluarga.

\section{School Readiness Pada Anak Berkebutuhan Khusus}

Individu berkebutuhan khusus memiliki beberapa dimensi perbedaan dengan anak normal, antara lain fisik, psikologis, atau sosial. Dari dimensi perbedaan itu muncul beberapa definisi dari para ahli. Definisi individu berkebutuhan khusus sering diinterpretasikan sama dengan beberapa istilah yaitu impairment, disability, dan handicapped. Perlu dipisahkan definisi istilah itu karena sebenarnya maknanya berbeda. Impairment sering dikaitkan dengan 
kondisi medis atau organis, adanya penyakit atau kerusakan dari suatu jaringan (Mangunsong, 2009). Misalnya terjadinya infeksi dalam kandungan yang menyerang janin (seperti rubella, toksoplasma, atau virus lain) sehingga bagian otak ada yang mengalami kerusakan sehingga bisa menjadikan anak mengalami cerebral palsy. Berikutnya disability berkaitan dengan konsekuensi fungsional dari kerusakan bagian dari tubuh yang berakibat pada tidak bisa untuk melakukan sesuatu. Misalnya anak yang tunanetra memiliki disability dalam penglihatan. Sedangkan handicapped merupakan konsekuensi sosial atau lingkungan dari kekhususannya. Ketidakmampuan ini belum tentu ada pada anak yang berada pada kondisi khusus. Misalnya anak yang tunanetra tetap bisa memainkan alat musik yaitu drum.

Individu berkebutuhan khusus dalam beberapa buku sering disebut sebagai anak berkebutuhan khusus yang menurut Hallahan, Kauffman, dan Pullen (2009) yaitu anak yang memiliki perbedaan dengan anak yang lain dari segi mental, fisik, ketidakmampuan belajar, gangguan atensi, emosi, atau perilaku, atau special gifts/talents. Lebih lanjut dijelaskan bahwa kekhususan yang dimiliki oleh anak sangat mungkin untuk berbeda dalam penyebab, tingkat keparahan, dan dampak bagi pendidikannya. Khusus pada pendidikannya diterapkan perbedaan cara belajar, misalnya instruksi berulang-ulang, kurikulum, materi, dan guru yang berbeda pula.

Individu yang mengalami keterbatasan dalam pertumbuhan dan perkembangan baik fisik, intelektual, emosi, dan social seringkali proses belajarnya terhambat. Ada banyak tantangan yang harus dihadapi oleh anak dan orang tua menyangkut bimbingan, kesiapan masuk sekolah, dan sistem sekolahnya. Meskipun demikian perlu diketahui jika individu berkebutuhan khusus dengan keterbatasannya tetap berhak mendapatkan pendidikan seperti anak-anak lainnya. anak-anak tersebut memiliki hak yang sama dalam memperoleh pendidikan dan pelayanan pemerintah. Ini sesuai dengan isi Undang-Undang Nomor 20 tahun 2003 Pasal 5 tentang sistem Pendidikan Nasional yang menyatakan bahwa "setiap warga Negara mempunyai hak yang sama untuk memperoleh pendidikan yang bermutu" (Pemerintah RI, 2010). Individu berkebutuhan khusus bisa memilih untuk belajar di sekolah inklusi, pendidikan khusus atau pelayanan khusus yang mendukung. Masing-masing jenis sekolah memiliki kelebihan dan kelemahannya sendiri, misalnya di Sekolah Luar Biasa yang biasanya siswanya memiliki diagnosis yang sama jika dilihat dari kelebihan siswa bisa belajar dari siswa yang lain. Akan tetapi kelemahannya siswa minim kesempatan untuk diperkenalkan dengan dunia sebenarnya yang heterogenitas.

Berbeda dengan sekolah inklusi yang mana individu bisa diperkenalkan dengan latar belakang siswa yang beragam. Tentu saja inklusi yang sebenarnya adalah inklusi yang membantu siswanya dapat menyesuaikan diri secara emosi dan social terhadap lingkungan. Oleh karena itu dibutuhkan kesiapan untuk belajar di sekolah. Seorang anak yang tidak memiliki kesiapan sekolah di sekolah inklusi akan mengalami hambatan dalam menjalani 
proses belajar. Slameto (2013) merumuskan kesiapan sebagai faktor yang memperngaruhi proses belajar, kesiapan itu sendiri didefinisikan sebagai kesediaan untuk memberikan respon atau reaksi. Kesiapan ini berkaitan dengan kematangan dan timbul dalam diri sendiri. Jika melihat dari kekhususan yang ada pada individu berkebutuhan khusus yaitu fisik, intelektual, emosi, dan social, maka kesiapan belajar juga melihat dari kekhususan itu. Artinya untuk bisa mengetahui anak siap atau tidak siap maka perlu dilihat dari empat kekhususannya.

Djamarah (2011) menyatakan kesiapan sekolah merupakan kondisi diri yang telah dipersiapkan untuk melakukan kegiatan di lingkungan sekolah. Tiga aspek yang mempenaruhi yaitu 1) kondisi fisik, metal, dan emosional, 2) kebutuhan atau motif tujuan, 3) ketrampilan dan pengetahuan yang dipelajari. Maxwell dan Clifford (2004) menyatakan bahwa kesiapan sekolah pada individu berkebutuhan khusus tidak hanya pada akademik, yang paling penting adalah kesiapan dalam hal social, emosial, dan kesehatan fisik.

\section{METODE PENELITIAN}

Rancangan Penelitian

Penelitian ini merupakan penelitian deskriptif kuantitatf yang berupaya untuk memaparkan kondisi situasi lingkungan dan subyek yang diteliti secara deskriptf dan menyajikan fakta-fakta temuan dengan menggunakan uraian.

\section{Subyek penelitian}

Subyek dalam penelitian ini adalah siswa berkebutuhan khusus, guru dan orangtua di 7 sekolah inklusi Batu.Teknik pengambilan sampel dalam penelitian ini adalah quota sampling, dimana seluruh sampel yang ada digunakan sebagai subyek penelitian. Dengan jumlah siswa berkebutuhan khusus di masing-masing sekolah adalah sebagai berikut:

Variable dan Instrumen Penelitian

Variable dalam penelitian ini adalah school readiness. Pengumpulan data menggunakan berbagai metode yang saling melengkapi, yang meliputi observasi pada siswa berkebutuhan khusus dan wawancara pada guru inklusi dan orangtua siswa berkebutuhan khusus. Metode selanjutnya yaitu menggunakan kuesioner school readiness yang disusun oleh para peneliti mengacu pada aspek dari school readiness yaitu aspek kognitif, sosial, emosi, motivasi dan bahasa. 


\section{HASIL DAN PEMBAHASAN}

Hasil Penelitian

Subjek penelitian ini adalah siswa inklusi di SDN Tlekung 1, SDN Junrejo 1 dan 2, serta SDN Mojorejo 1 yang memiliki kebutuhan khusus yakni: ADHD, Autis, Autis dan C1, Disleksia, Down Syndrom, Gangguan konsentrasi, Retardasi Mental, Retardasi Mental Sedang (Down Syndrom), Retardasi Mental Sedang dan Hiperaktifitas, Slow Learner, Tuna Daksa, Tuna Grahita, Tuna Rungu, Tuna Rungu dan Borderline. Adapun data lengkap mereka sebagi berikut:

Tabel 1. Tabel demografi subjek $(\mathrm{N}=31)$

\begin{tabular}{lll}
\hline Deskripsi & F & $\%$ \\
\hline Jenis Kelamin & & \\
$\quad$ Laki-laki & 21 & 68 \\
$\quad$ Perempuan & 10 & 32 \\
\hline Sekolah & & \\
SDN Junrejo 1 & 8 & 26 \\
SDN Junrejo 2 & 3 & 10 \\
SDN Mojorejo 1 & 9 & 29 \\
SDN Tlekung 1 & 11 & 35 \\
\hline Usia & & \\
7-12 tahun & 24 & 77 \\
13-18 tahun & 7 & 23 \\
\hline
\end{tabular}

Berdasarkan table tersebut diketahui bahwa siswa berkebutuhan khusus di kelas inklusi lebih banyak berjenis kelamin laki-laki serta rata-rata usia antara 7 sampai 12 tahun. Adapun jumlah siswa inklusi yang paling banyak terdapat di SDN Tlekung 1 yaitu 11 orang siswa diikuti oleh SDN Mojorejo 1 sebanyak 9 orang siswa dan Junrejo 1 sebanyak 8 orang siswa.

1. Gambaran school readiness siswa inklusi ditinjau dari aspek kognitif, Sosial, Emosi, Motivasi dan bahasa.

\section{Readiness for School}

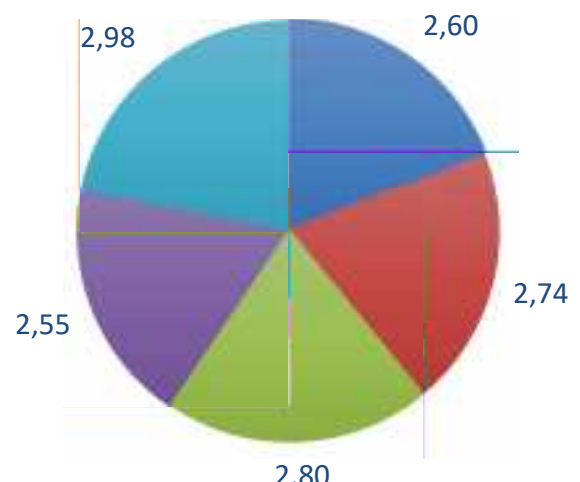

2,80

- Kognitif Sosial Emosi notivasi Bahasa 
Dari table 2 diketahui bahwa kesiapan sekolah lebih banyak pada aspek bahasa sebesar 2,98\%, diikuti aspek emosi sebesar 2,80\% dan aspek sosial sebesar Sosial sebesar $2,74 \%$.

2. Gambaran School Readiness siswa inklusi ditinjau dari aspek kognitif

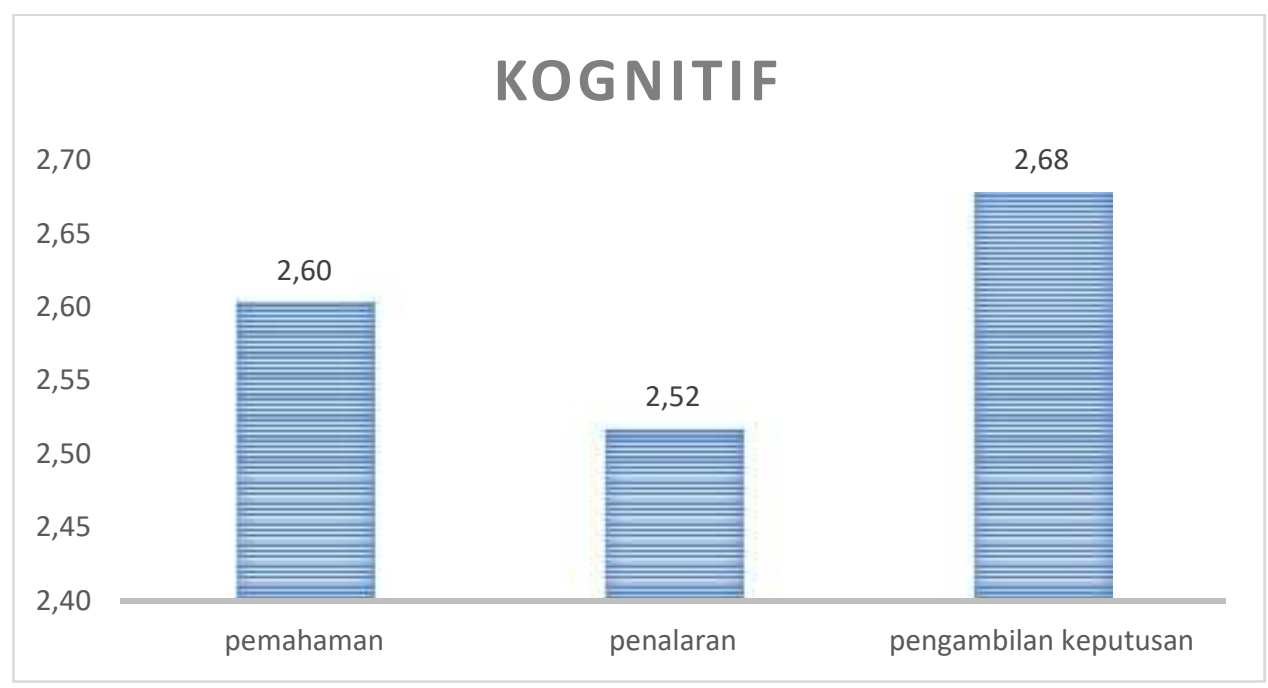

Dari table tersebut diketahui bahwa dari aspek kognitif tampak bahwa aspek pengambilan keputusan memiliki prosentase terbesar yaitu sebesar 2,68\% dibanding aspek pemahaman $(2,60 \%)$, dan penalaran $(2.52 \%)$.

3. Gambaran School Readiness siswa inklusi ditinjau dari aspek Sosial

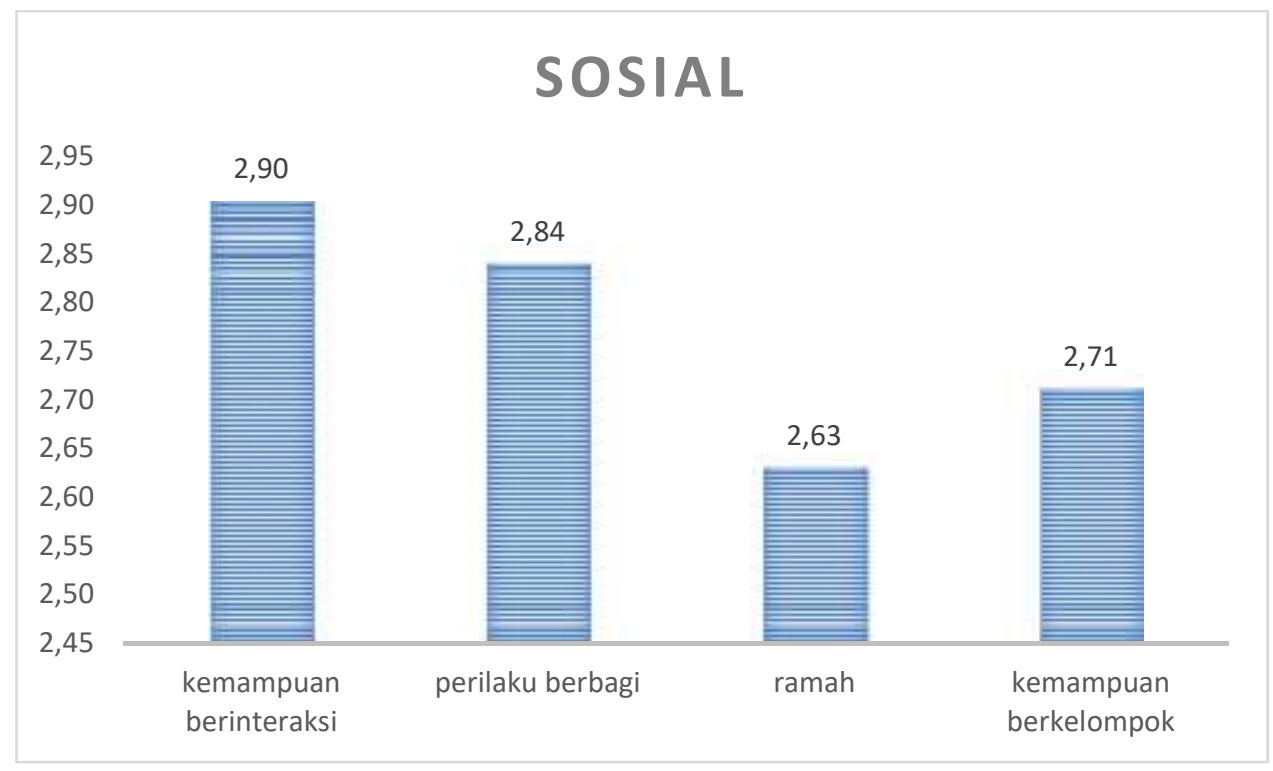

Dari aspek sosial, diketahui bahwa kemampuan berinteraksi memiliki prosentase terbesar yaitu 2,90\%, diikuti aspek Perilaku berbagi sebesar 2,84\% serta kemampuan berkelompok sebesar $2,71 \%$. Sementara aspek ramah hanya sebesar $2,63 \%$. 
4. Gambaran school readiness siswa inklusi ditinjau dari aspek Emosi

\section{EMOSI}

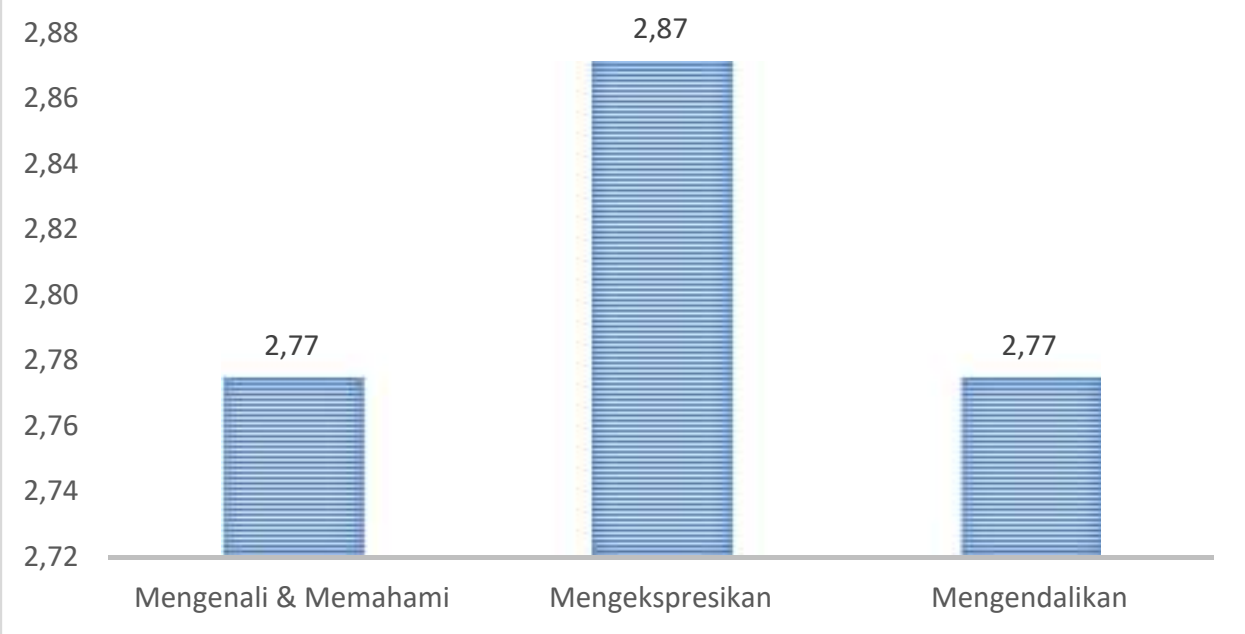

Dari aasek emosi, kemampuan mengekspresikan diri menjadi aspek yang menentukan kesiapan sekolah siswa berkebutuhan khusus dengan prosentase sebesar 2, $87 \%$. Sementara aspek engenali dan memahami serta pengendalian dari memiiliki prosentase yang sama besar yaitu $2,77 \%$.

5. Gambaran school readiness siswa inklusi ditinjau dari aspek motivasi

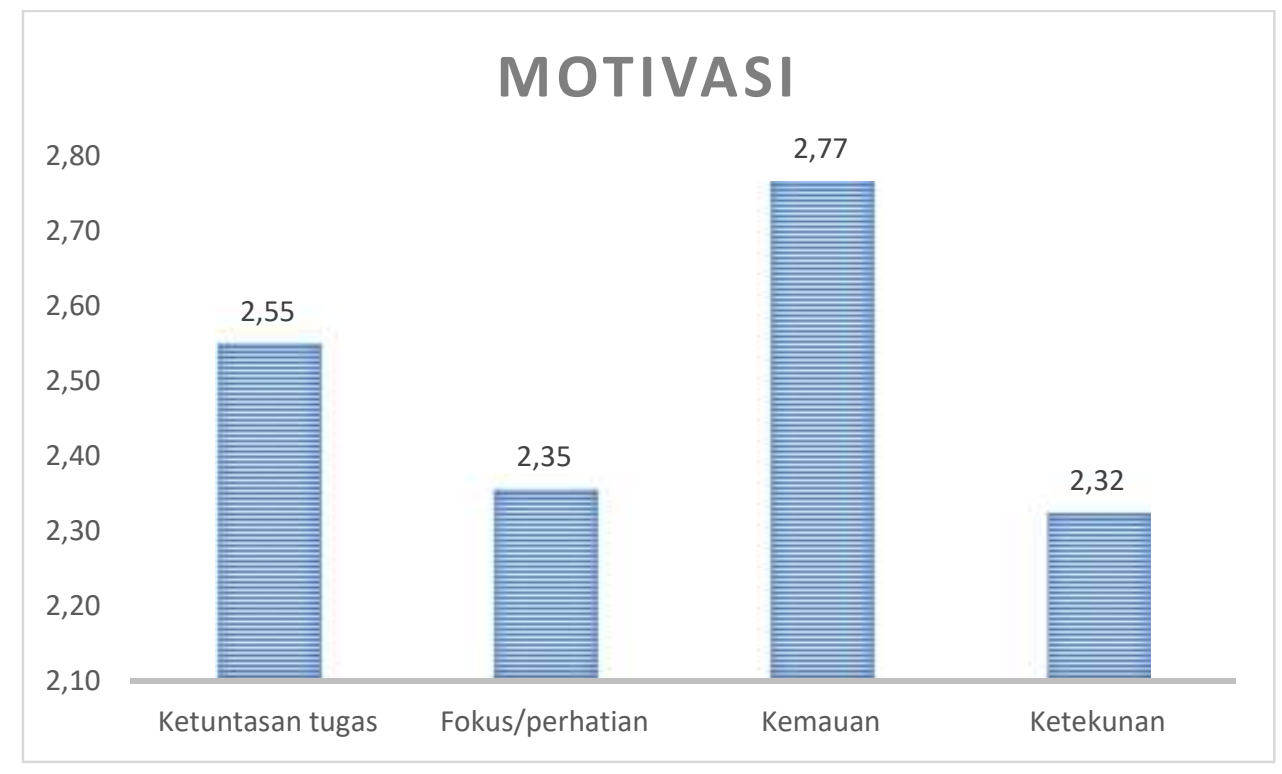

Dari Aspek motivasi, indicator kemauan menjadi penentu terbesar dari kesiapan sekolah siswa bekebutuhan khusus dengan prosentase sebesar $2,77 \%$, diikuti indikatir ketuntasan menyelesaikan tugas sebesar $2,55 \%$. Sementara aspek focus sebesar $2,35 \%$ dan ketekunan $2,32 \%$. 
6. Gambaran school readiness siswa inklusi ditinjau dari aspek Bahasa/Komunikasi

\section{BAHASA/KOMUNIKASI}

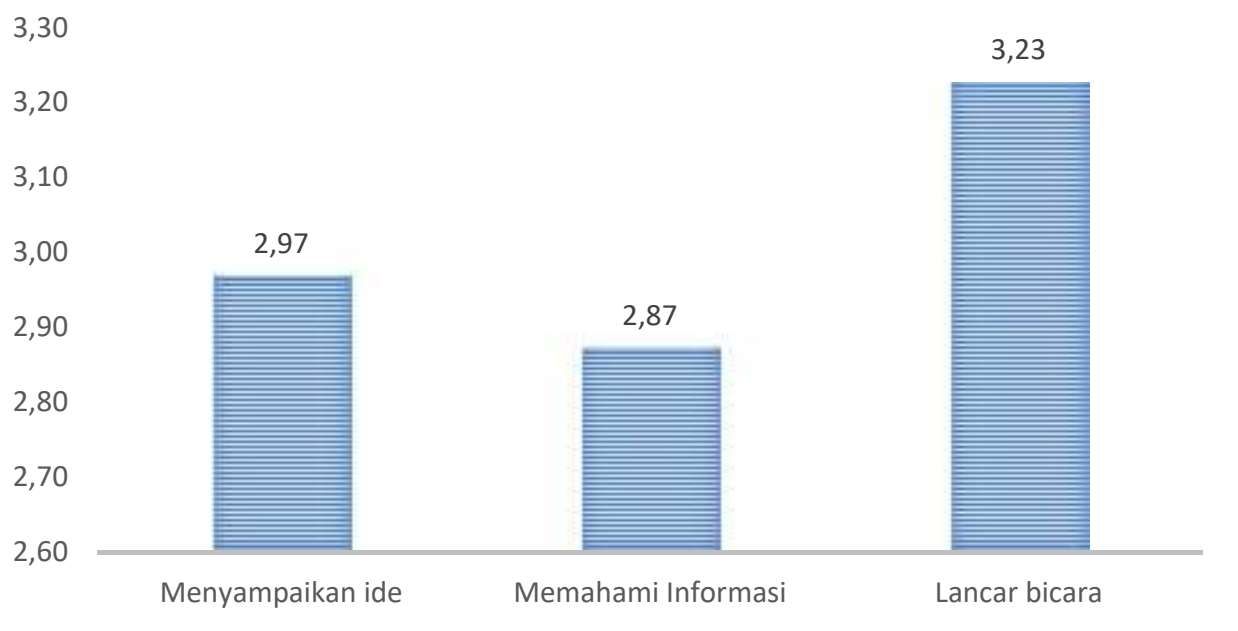

Dari tabel tersebut diketahui bahwa dalam komunikasi, aspek yang menentukan kesiapan sekolah siswa berkebutuhan khusus adalah aspek lancar dalam berbicara dengan prosentase sebesar 3,23\% diikuti kemampuan menyampaikan ide (2,97\%) dan Kemampuan memahami informasi (2,87\%).

7. Gambaran school readiness siswa berkebutuhan khusus di kelas inklusi ditinjau dari jenis kelamin

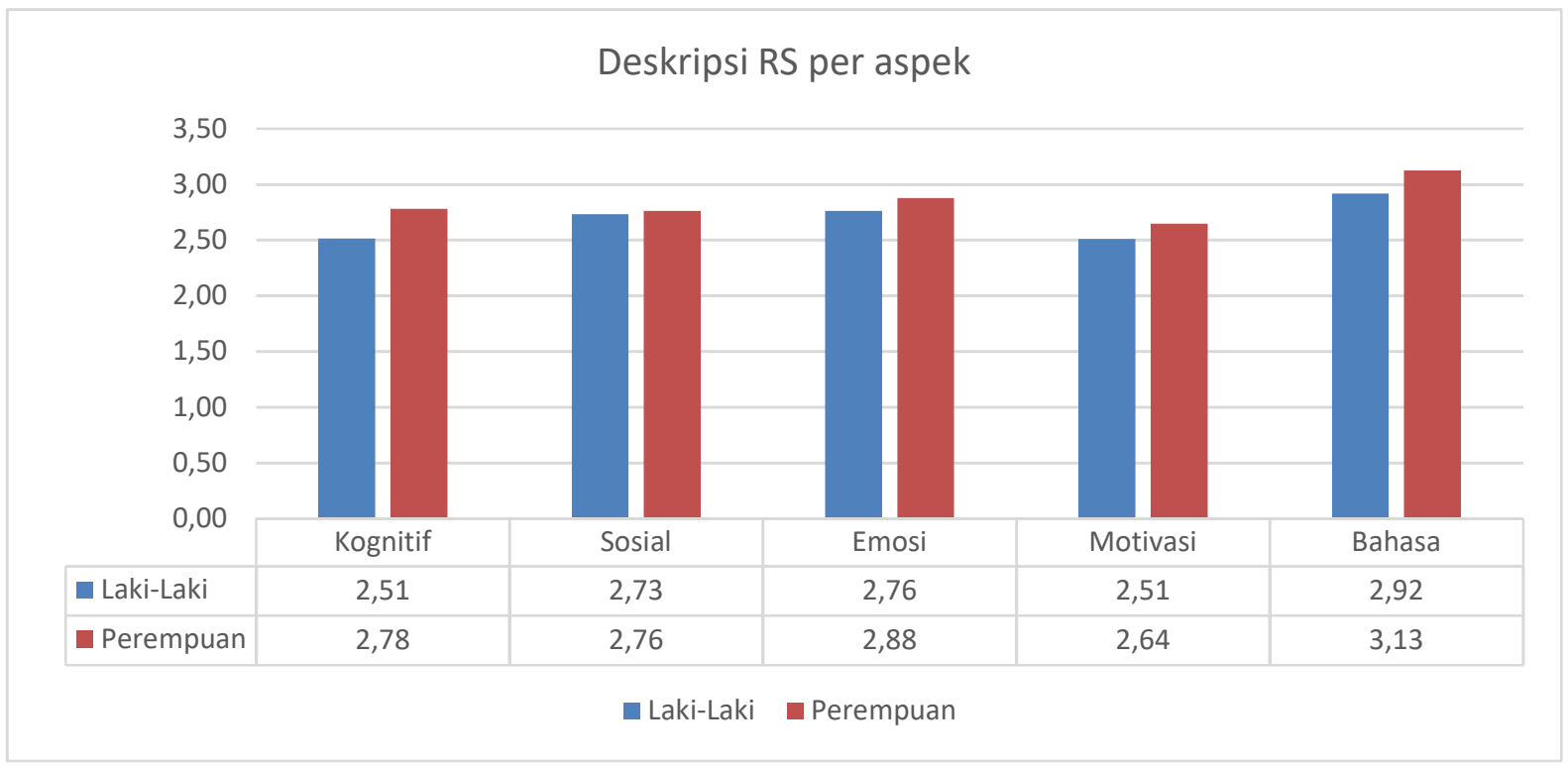

Dari tabel tersebut diketahui bahwa siswa berkebutuhan khusus dengan jenis kelamin perempuan memiliki kesiapan sekolah yang lebih tinggi dibanding siswa berkebutuhan khusus laki-laki. Hal ini tampak dari 3 aspek dominan yaitu kemampuan bahasa, siswa perempuan memiliki kesiapan sekolah lebih tinggi (3,13\%) dibanding laki-laki $(2,92)$, Kemudian Aspek 
Emosi, siswa perempuan memiliki kesiapan sebesar 2,88\% lebih tinggi dibanding laki-laki $(2,76 \%)$, begitu pun dari aspek kogniti, siswa perempuan memiliki kesiapan kognitif yang lebih tinggi $(2,78 \%)$ dibanding siswa laki-laki $(2,51 \%)$.

\section{DISKUSI}

Berdasarkan hasil penelitian menunjukkan bahwa terdapat aspek-aspek school readiness pada siswa berkebutuhan khusus meliputi empat aspek, yaitu kognitif, sosial, emosi, motivasi, dan bahasa. Dari kelima aspek yang ada, diketahui bahwa aspek yang utama dalam school readiness adalah bahasa. Bahasa ini menyangkut kemampuan bahasa yang disampaikan dan kefasihan bahasa termasuk kemampuan komunikasi. Kemampuan bahasa dan komunikasi akan mengarahkan anak untuk berinteraksi dengan individu yang lain. Dalam komunikasi ini yang diperoleh tidak hanya sebatas pada percakapan yang bersifat informative tetapi yang lebih penting pada tercapainya pemahaman suatu pesan yang bersifat non verbal (Lipscomb, Pratt, Schmitt, Pears, dan Kim (2013). Lebih lanjut aspek bahasa mengarah pada perbendaharaan kata yang dimiliki oleh siswa berkebutuhan khusus. Aspek bahasa ini termasuk tatabahasa terdiri dari kaidah untuk meletakkan kata-kata atau isyarat atau simbol bersama-sama. Komunikasi bisa berjalan dengan baik jika dilakukan dengan bahasa yang tersistematis.

Beberapa siswa berkebutuhan khusus ada kemungkinan memiliki kemampuan berbicara, misalnya pada anak down syndrome, tetapi seringkali ditemui mereka tidak terampil berbahasa. Contohnya anak-anak yang mampu mengulang beberapa kata yang diucapkan orang lain kepadanya dengan baik, tetapi dia tidak mengetahui arti dari kata itu. Pada anak autis misalnya, ia hanya mampu membentuk komunikasi melalui tersenyum atau tangisan seperti pada komunikasinya bayi sehingga minim bahasa yang diperoleh. Di sisi lain ada anak yang memiliki kemampuan bahasa tetapi tidak bisa berbicara, ini terjadi pada anak yang mengalami tunarungu level berat. Bisa disimpulkan ketika anak berkomunikasi, maka ia sedang menggunakan bahasa.

Lebih lanjut, aspek bahasa ini akan berpengaruh pada kemampuan membaca dan menulis, dimana kedua aktivitas ini sering digunakan sebagai indikator anak siap atau tidak untuk sekolah. Di dalam kedua aktivitas ini dibedakan menjadi empat bentuk kemampuan yaitu 1) kemampuan pemahaman membaca "huruf, 2) kemampuan pemahaman membaca "kata", 3) kemampuan intonasi dalam membaca "kalimat", dan 4) kemampuan membaca "pemahaman". Empat bentuk kemampuan yang berkaitan dengan bahasa dan komunikasi itu sesuai dengan hasil analisa dimana gambaran yang paling utama adalah lancar bicara, kemudian menyampaikan ide, dan terakhir memahami informasi. Untuk bisa dikatakan siap sekolah, anak harus lancar dalam berbicara sehingga orang yang diajak berinteraksi memahami maksud dari apa yang dibicarakan. Ketika anak berkebutuhan khusus sudah 
memiliki kemampuan dalam berbicara maka disusul oleh kemampuan lain yaitu ia akan percaya diri menyampaikan ide, dan paling terakhir ia akan memahami informasi secara utuh. Bagi anak-anak berkebutuhan khusus yang belum memiliki ketrampilan bicara, maka diberikan terapi wicara. Dari uraian diatas dapat disimpulkan bahwa bahasa dan komunikasi ini penting sebagai prasyarat anak berkebutuhan khusus dikatakan school readiness.

Aspek kedua yang menunjukkan siswa berkebutuhan khusus school readiness adalah aspek emosi. Seperti dijelaskan pada awal bab jika ciri-ciri pada anak berkebutuhan khusus adalah sisi emosinya, dalam memahami school readiness ini penting untuk menjelaskan aspek emosi. Secara umum anak berkebutuhan khusus memiliki emosi yang hampir berbeda dengan anak-anak yang normal, tentu saja kematangan emosinya ini juga tidak lepas dari jenis kekhususan dan level dari kekhususannya. Emosi pada anak berkebutuhan khusus menyangkut ekspresi emosi, mengenali dan memahami emosi, serta mengendalikan atau kontrol emosi. Anak berkebutuhan khusus cenderung kesulitan untuk mengekspresikan emosi yang dirasakan, terutama pada anak autis dan ADHD. Castelli (2005) menyatakan bahwa anak autis mengalami kesulitan dalam kontak afeksi dengan orang lain sehingga sulit untuk mempelajari ekspresi orang lain dan kesulitan mengekspresikan emosinya. Pada aspek ini juga bisa dijelaskan secara biologis, yaitu bagian emosi diatur oleh sistem limbik. Sistem ini berada pada salah satu bagian otak yang mengalami kelainan pada anak autis, padahal sistem ini memiliki peranan penting dalam emosi. Gangguan pada sistem limbik yang merupakan pusat emosi berakibat pada kesulitan mengendalikan emosi, temper tantrum, marah, menangis, dan takut pada hal-hal tertentu.

Aspek emosi ini juga berkaitan erat dengan munculnya salah penafsiran informasi emosional yang ada di sekeliling anak sehingga reaksi emosi yang muncul terkadang tidak tepat dengan situasinya. Pada anak berkebutuhan khusus yang memiliki hambatan dalam emosinya ini, juga berpengaruh pada kesiapan sekolahnya. Anak akan siap sekolah jika telah mampu mengekspresikan emosi yang dimulai dari mampu mengenali emosi yang dirasakannya. la juga telah memiliki strategi sendiri untuk mengatur emosi yang muncul sehingga emosi baik positif maupun negatif bisa diregulasi dan dikendalikan. Pada tahapan terakhir maka anak telah siap untuk memasuki sekolah.

Aspek ketiga adalah aspek sosial yaitu kemampuan hubungan sosial dan kognisi sosial. Pada aspek ini juga dikatakan sebagai syarat siswa school readiness. Anak berkebutuhan khusus memiliki hambatan di dalam membangun interaksi dengan orang lain, meskipun tidak menutup kemungkinan ada sebagian kecil anak-anak yang tidak memiliki hambatan yang berarti di dalam sosialnya. Anak-anak berkebutuhan khusus yang sering terhambat dalam sosialnya adalah jenis anak dengan down sydrome (retardasi mental), autis, dan ADHD. Hambatan pada aspek sosial ini sebagai akibat dari hambatan komunikasi sehingga anak-anak berkebutuhan khusus seringkali maladjusment atau kegagalan 
menyesuaikan diri sehingga seringkali juga tertolak oleh lingkungan. Sering dijumpai pada anak-anak berkebutuhan khusus ini kesulitan berkomunikasi dengan teman sebaya, sehingga teman sebaya tidak paham dengan apa yang dimaksud akhirnya ia mudah dijauhi oleh temantemannya. Bisa juga muncul karena ketidakmampuan mengontrol emosi dan perilakunya maka ia akan dijauhi pula oleh teman-temannya.

Aspek keempat adalah kognitif, yang didefinisikan dengan kemampuan memahami, kemampuan menalar, dan pengambilan keputusan. Jika melihat dari hasil, ternyata komponen utama aspek kognitif adalah pengambilan keputusan. Hal ini memperlihatkan jika anak berkebutuhan khusus pola pikirnya lebih pada konkrit, artinya ia lebih mampu untuk menyelesaikan persoalan pada situasi nyata atau konkrit. Oleh karena itu anak berkebutuhan khusus akan lebih mudah memahami ketika pembelajaran di sekolah menggunakan alat-alat peraga. Ini bisa dikembangkan oleh lingkungan sekolah untuk memanfaatkan lingkungan sekitar sebagai lingkungan belajar. Anak berkebutuhan khusus akan mudah memahami dengan bahan belajar dari lingkungan sekitarnya yang bersifat nyata. Pada perkembangan berikutnya jika anak telah memiliki aspek ini, maka kemampuan pemahaman (comprehension skill) akan terbentuk yang berguna untuk problem solving-nya (Madan \& Sharma, 2013). Problem solving ini berguna dalam pengambilan keputusan, terutama keputusan yang menyangkut dirinya sendiri. Hal mendasar yang harus dimiliki oleh anak ketika mengambil keputusan adalah kematangan pribadi. Pengambilan keputusan ini menjadi suatu hal yang biasa dilakukan karena setiap individu pasti menghadapi permasalahan dan sebagai kunci terpenting untuk dapat mempertahankan hidup. Anak yang lemah dalam pengambilan keputusan cenderung ragu-ragu bahkan ketakutan sehingga menjadi tidak siap untuk sekolah. Meskipun memiliki kekhususan dan hambatan pada beberapa aspek, perlu untuk membentuk dan mengajarkan problem solving supaya ia terlatih untuk memecahkan masalah, termasuk ketika anak akan masuk di lingkungan sekolah. Apabila anak telah memiliki kemampuan ini, guru perlu membekali lagi kemampuan berpikir kritis dan keratif. Kritis menganalisis dan kreatif melahirkan alternatif pemecahan masalah. Kedua jenis pemikiran ini sebenarnya telah ada sejak lahir, akan tetapi karena ABK mempunyai keterbatasanketerbatasan dalam berpikir maka kedua jenis pemikiran ini perlu dilatih dan diasah terus. Meskipun memiliki keterbatasan dalam berpikir, tidak menutup kemungkinan ABK memiliki kelebihan yang ia miliki yang membantunya ketika ia berada di sekolah.

Aspek terakhir yang menjadi indikator anak siap atau tidak siap sekolah adalah aspek motivasi. Aspek ini berisi kemauan anak untuk memulai sendiri melakukan aktivitas atau mengerjakan tugasnya. Anak berkebutuhan khusus seringkali memiliki kesadaran yang rendah untuk mau menyelesaikan tugas-tugasnya. Perlu dukungan dari orang lain untuk tetap menjaga motivasinya. la juga mudah sekali putus asa ketika dihadapkan pada persoalan yang menuntutnya untuk diselesaikan. 
Melihat hasil penelitian, dapat dijelaskan bahwa school readiness itu tidak terbatas pada satu atau dua aspek, tetapi ada lima aspek yang terkait satu dengan yang lainnya. Anak berkebutuhan khusus dengan segala keterbatasannya akan siap untuk sekolah apabila aspek-aspek mulai bahasa, emosi, sosial, kognitif, dan motivasi ada dalam diri anak itu. Hasil penelitian sesuai dengan definisi dari school readiness yang disampikan oleh Denton (2000) dan Schoen dan Nagle (2004) bahwa school readiness atau kesiapan belajar tidak terbatas pada satu area perkembangan atau fungsi, melainkan merupakan hubungan yang timbal balik antara ketrampilan dan perilaku melalui aspek perkembangan dan belajar. Anak akan siap bersekolah ketika ia terlatih memanfaatkan perkembangan yang ada pada dirinya. Berikutnya, jika aspek school readiness ini dirinci akan terlihat aspek yang paling menonjol sebagai indikator readiness for school ini adalah aspek bahasa. Kekayaan kosakata pada diri anak memberikan sumbangan yang besar untuk ketrampilan komunikasinya. Aspek ini juga berpengaruh pada aspek yang lain seperti sosial dan motivasi. Anak akan mampu bersosialisasi dengan baik ketika ia terampil berbicara dan berkomunikasi. Sedangkan aspek kognitif menjadi aspek ketiga. Ini bisa menjadi masukkan untuk guru-guru yang mengajar anak berkebutuhan khusus bahwa siswa berkebutuhan khusus itu tuntutannya bukan pada segi kognitif. Sering dijumpai di sekolah inklusi dikatakan anak berhasil di sekolah ketika ia memiliki prestasi akademik. Paradigma guru-guru ABK perlu diubah sehingga melihat keberhasilan siswa berkebutuhan khusus itu yang utama tidak pada sisi kognitif, tetapi kemampuan bahasa dan emosi. Hasil ini sesuai dengan penjabaran Maxwell dan Clifford (2004) yang menyatakan kesiapan sekolah pada individu berkebutuhan khusus tidak hanya pada akademik, tetapi yang paling penting dari itu adalah kesiapan dalam hal social, emosial, dan kesehatan fisik.

Hasil penelitian ini juga menunjukan bahwa ada perbedaan kesiapan sekolah pada siswa berkebutuhan khusus laki-laki dan perempuan, dimana siswa berkebutuhan khusus dengan jenis kelamin perempuan memiliki kesiapan sekolah yang lebih tinggi dibanding siswa berkebutuhan khusus laki-laki, hampir pada semua aspek kesiapan belajar.

Penelitian ini tidak lepas dari keterbatasan yang menyertai, antara lain jenis anak berkebutuhan khusus yang belum terpetakan dengan baik. Artinya dalam melihat readiness for school pada ABK akan menghasilkan data lebih banyak jika jenis ABK telah diasesmen sebelumnya sehingga akan bisa dilihat bagaimana readiness for school pada masing-masing jenis ABK tertentu.

\section{KESIMPULAN DAN SARAN}

Kesimpulan

Berdasarkan analisa data, diketahui hasil penelitian ini sebagai berikut:

1. School readiness pada siswa berkebutuhan khusus meliputi empat aspek, yaitu kognitif, sosial, emosi, motivasi, dan bahasa. 
2. Dari kelima aspek yang ada, diketahui bahwa aspek yang utama dalam school readiness adalah bahasa diikuti aspek emosi dan aspek sosial.

3. Hasil penelitian ini juga menunjukkan bahwa siswa berkebutuhan khusus laki-laki dan perempuan memiliki kesiapan sekolah yang berbeda dimana siswa berkebutuhan khusus dengan jenis kelamin perempuan memiliki kesiapan sekolah yang lebih tinggi dibanding siswa berkebutuhan khusus laki-laki, hampir pada semua aspek kesiapan belajar.

Saran

Bagi peneliti selanjutnya diharapkan:

1. Meneliti school readiness pada siswa berkebutuhan khusus dengan karakteristik yang sama.

2. Mengaitkan aspek school readiness dengan variable lain seperti kondisi sekolah dan dukungan orangtua. 


\section{DAFTAR PUSTAKA}

Abram, T. (2012). Determining if your child is ready for school involves more than just academic and social-emotional abilities. http://msue.anr.msu.edu/news/school_readiness_factors.

Brazelton, T. B., \& Greenspan, S. I. (2000). The irreducible needs of children: What every child must have to grow, learn, and flourish, Perseus Publishing, Cambridge, Mass.

Britto, P., Fuligni, A. S., \& Brooks-Gunn, J. (2003). Reading, rhymes, and routines: American parents and their children, The Health and Social Conditions of Young Children in American Families, edited by Neal Halfon, Katherine Taaffe McLearn and Mark A. Schuster, Cambridge University Press, Cambridge, pp. 117-145.

Castelli, F. (2005). Understanding emotions from standardized facial expressionsnin autism and normal development. SAGE publications and the national autistic society, 9, (4), 428-449.

COUNCIL ON EARLY CHILDHOOD; COUNCIL ON SCHOOL HEALTH.. (2016). The Pediatrician's Role in Optimizing School Readiness. DOI: 10.1542/peds.2016-2293

DeAnna M. Laverick; Mary Renck Jalongo. (2011). Transitions to early care and education. New York: Springer

Direktorat Pembinaan Sekolah Luar Biasa, Direktorat Jenderal Manajemen Pendidikan Dasar dan Menengah, Departemen Pendidikan Nasional. (2007). Model pembelajaran dan pendidikan penyelenggaraan Pendidikan Inklusif: Pedoman Umum Penyelenggaraan Pendidikan Inklusif.

Djamarah, S. B. (2011). P sikologi belajar. Jakarta: PT. Rineka Cipta.

Direktorat Pembinaan Sekolah Luar Biasa, Direktorat Jenderal Manajemen Pendidikan Dasar dan Menengah, Departemen Pendidikan Nasional. (2007). Model pembelajaran dan pendidikan penyelenggaraan Pendidikan Inklusif: Pedoman Umum Penyelenggaraan Pendidikan Inklusif.

Direktorat Pembinaan PEndidikan Khusus dan Layanan Khusus. (2010) Pedoman Umum Penyelenggaraan Pendidikan Inklusif. Jakarta: Kemendiknas.

Elizabeth Votruba-Drzal., \& Eric Dearing. (2017). Handbook of Early Childhood Development Programs, Practices, and Policies., John Wiley \& Sons, Jan 30, 2017 - Psychology 552 pages

Gesell, A., Ilg, F. L., \& Ames, B. L. The child from Five to Ten (Harper \& Row, New York 1977) p. 47

Graue, M.E. (1992). Readiness, instruction and learning to be a kindergartner. Early Education and Development, 3, (2), 92-114. 
Denton, K., \& Elvira Germino-Hausken. (2000). America's kindergartners (NCES 2000-070), U.S. Department of Education, National Center for Education Statistics, Washington D.C.

Hallahan, D.P., Kauffman, J.M, Pullen, P.C. (2009). Exceptional Learners. An Introduction to Special Education. Pearson Education, Inc: United State of America.

Heriot, S \& Beale, I. (2004). Is your child ready for school ? : a guide for parents. Melbourne: Shannon Books.

Lipscomb, S. T., Pratt, M. E., Schmitt, S. A., Pears, K. C., \& Kim, H. K. (2013). School readiness in children living in non-parental care: Impact of head start. J ournal of applied developmental psychology, 34, (1), 23-37.

Madan, A., \& Sharma, N. (2013). Inclusive education for children wth disabilities: Preparing schools to meet the challenge. J ournal for inclusive education, 3, (1), 1-23, 2013.

Mangunsong, F.(2009). Psikologi dan pendidikan anak berkebutuhan khusus.jilid 1. LPSP3UI: Jakarta.

(2011). Psikologi dan pendidikan anak berkebutuhan khusus. Jilid 2. LPSP3UI: Jakarta.

Maxwell, K., \& Clifford, R.M. (2004). Research in review: School readiness assessment. Young Children, 59, 42-46.

Munandar, S.C.U. (1985). Mengembangkan bakat dan kreativitas anak sekolah. Grasindo. Jakarta.

Murphy, D. A., \& Catherine, E. B. Development of a comprehensive community assessment of school readiness. Early Childhood Research and Practice, 4, (2),1-15.

National Education Goals Panel. (1995). The National E ducation Goals Report (1995) Building a Nation of Learners. https://eric.ed.gov/?id=ED389097

New, R. S., \& Cochran, M. (2007). Early childhood education: An international encyclopedia, Volumes 1-4. London: Praeger Publishers.

Ni'matuzahroh \& Nurhamida, Y. (2014). Pengembangan model pendidikan inklusi berbasis komunitas. Hibah Bersaing DIKTI.Universitas Muhammadiyah Malang.

OíNeil, J. (1997). Building schools as communities: A conversation with James Comer. Educational Leadership, 54, 6-10.

Raver, C. C. (2004). 'Placing emotional self-regulation in sociocultural and socioeconomic contexts', Child Development, 75, (2), 346-353.

Snow, C. E., Burns, M. S., \& Griffin, P. (1998). P reventing reading difficulties in young children. National Academy Press, Washington, D.C.,

Villegas, A. M., \& Lucas, T. (2002). Preparing culturally responsive teachers: rethinking the curriculum, J ournal of Teacher E ducation, 53, (1), 20-32. 
Whitehurst, G. J., \& Lonigan, G. J. (1998). Child development and emergent literacy, Child development, 69, (3), 848-872.

Slameto. (2010). Belajar dan factor-faktor yang mempengaruhinya. Jakarta: PT. Rineka Cipta.

Smith, J.D. (2012). Sekolah Inklusif: Konsep dan Penerapan Pembelajaran. Penerbit Nuansa: Bandung.

Unicef. (2012). School Readiness: a conceptual framework. New York. https://www.unicef.org/education/files/Chil2Child_ConceptualFramework_FINAL(1).p df

Woolfson, R. (1995). Starting school. Great Britain: Harper Collins Manufacturing 